\title{
Defense against epibiosis in the sponge Mycale adhaerens: modulating the bacterial community associated with its surface
}

\author{
On On Lee, Stanley C. K. Lau, Pei-Yuan Qian* \\ Department of Biology/Coastal Marine Laboratory, The Hong Kong University of Science and Technology, Clear Water Bay, \\ Kowloon, Hong Kong, SAR
}

\begin{abstract}
It has long been hypothesized that sponges can produce bioactive compounds to modulate bacterial communities on their body surfaces and that the modulated bacterial communities can protect the sponge host from being colonized by other invertebrates. Conventionally, testing of this hypothesis has relied on bioassays involving bacteria isolated from ecologically relevant sites. However, this approach generally suffers from the fact that only $<1 \%$ of the total bacterial population in the natural environment is culturable using existing techniques. In this study, a bacterial cultureindependent method was employed to investigate if the metabolites of the sponge Mycale adhaerens could render surface-colonizing bacterial communities inhibitive to larval settlement of Hydroides elegans, a polychaete worm that co-exists with $M$. adhaerens in Hong Kong waters. Organic extracts of the sponge tissue were immobilized in hydrogels and then exposed to a continuous flow of natural seawater for the development of microbial films. Epifluorescence microscopy and DNA fingerprinting analysis of bacterial community in the microbial films revealed that the extracts drastically altered bacterial community composition on the hydrogel surfaces. Subsequently, these microbial films demonstrated either an anti-settlement or toxic effect on the larvae of $H$. elegans. These results suggested that sponge extracts can potentially prevent epibiosis via the modulation of spongeassociated bacterial communities.
\end{abstract}

KEY WORDS: Mycale adhaerens $\cdot$ Hydroides elegans $\cdot$ Surface bacterial community $\cdot$ Bioactive compounds $\cdot$ Bacterial density $\cdot$ Culture-independent method $\cdot$ Hydrogels

\section{INTRODUCTION}

The life cycle of many marine sessile organisms includes a free-living planktonic larval stage. Larvae may spend hours to months in the water column before settling on a substratum and eventually developing into adults. Larvae may settle on virtually any surface deemed suitable for their subsequent growth and survival, including the body surfaces of other organisms. For soft-bodied invertebrates, such as corals, sponges and ascidians, the consequences of allowing larvae of other organisms to settle on their body surfaces (i.e. epibiosis) can be detrimental. For instance, epibiotic organisms may obstruct feeding, gas exchange and waste excretion in the hosts, and compete with the hosts for nutrients and resources (Witman \& Suchanek 1984, Davis et al. 1989, Wahl 1989, Lesser et al. 1992). Furthermore, the hosts may suffer from tissue damage or reduced growth due to an increase in weight, rigidity and drag (Dixon et al. 1981, Keough 1984, Wahl \& Mark 1999).

It is a widely accepted ecological concept that softbodied invertebrates have evolved defensive mechanisms to prevent epibiosis. These mechanisms are believed to involve the production of bioactive compounds which inhibit larval settlement of epibiotic organisms. A number of low-molecular weight, antilarval settlement substances have been discovered from sponges (Keifer et al. 1991, Hirota et al. 1996, Okino et al. 1996), gorgonian corals (Standing et al. 
1984, Gerhart et al. 1988) and ascidians (Davis \& Wright 1990). There is growing evidence for the hypothesis that soft-bodied invertebrates may produce bioactive compounds to modulate the bacterial communities associated with their body surfaces so as to render their body surfaces unsuitable for larval settlement of epibiotic organisms (Lee \& Qian 2003, Dobretsov \& Qian 2004, Dobretsov et al. 2005). This hypothesis is largely based on the following 3 arguments. Firstly, all surfaces submerged in the marine environment, including those of soft-bodied invertebrates, are covered with microbial films, which are mainly composed of bacteria, fungi, algae and protozoa (Wahl 1989). Secondly, the body tissues of many soft-bodied invertebrates (e.g. soft-corals and sponges) are rich in antibacterial compounds (Amade et al. 1987, Aceret et al. 1998). Thirdly, it is believed that the composition and physiology of microbial films, especially the bacterial population, can have drastic effects on larval settlement of many marine invertebrates (Wieczorek \& Todd 1997, Maki 1999, Harder et al. 2002, Qian et al. 2003).

Previous investigations of this hypothesis have mainly relied on the standard agar disc-diffusion assay to demonstrate antibacterial effects of bioactive compounds produced by soft-bodied invertebrates (Acar 1980). However, the agar disc diffusion assay, which was originally developed for clinical testing of antibiotics on pure bacterial cultures, has limited applicability for ecological studies. The limitation is largely due to the fact that only an insignificant proportion $(<1 \%)$ of bacteria living in natural habitats is culturable using existing techniques (Pace 1996). Therefore, investigations relying on culturable bacteria to reveal the effects of bioactive substances on natural bacterial community usually result in rather fragmented and more speculative conclusions (Harder et al. 2004). Moreover, in almost all previous studies, efforts have been made to examine either the antimicrobial activities of bioactive compounds from soft-bodied invertebrates or the antilarval settlement activities of the associated microbes. The correlation between antimicrobial activities with reduced larval settlement has rarely been examined in detail.

The sponge Mycale adhaerens usually occurs in well-established benthic communities where open substratum space is limited; its body surface is constantly under the pressure of colonization by other organisms, such as the larvae of many benthic invertebrates, but is rarely fouled. By demonstrating an inhibitive effect of the waterborne metabolites from M. adhaerens on larval settlement of Hydroides elegans (a polychaete that is usually found in the same habitat of $M$. adhaerens but not on its surface), our previous investigation suggested a direct protective role of sponge metabolites against epibiosis (Lee \& Qian 2003). The aim of this study was to investigate a possible indirect protective role of sponge metabolites against epibiosis via the modulation of bacterial communities associated with the surface of $M$. adhaerens. To overcome the limitations and biases due to utilization of bacterial-culture-dependent assay techniques, we employed a recently developed culture-independent technique, in which organic extracts of sponge tissue were embedded into hydrogel matrix. The hydrogels were then exposed to the natural bacterial population in flow-through seawater for the development of microbial films. Hydrogels coated with microbial films were subsequently subject to larval settlement bioassay. The effect of sponge extract on modulation of bacterial community was analyzed using epifluorescence microscopy and a DNA fingerprinting technique.

\section{MATERIALS AND METHODS}

Collection and extraction of sponge tissue. Mycale adhaerens was collected at a fish farm in Long Harbour, Hong Kong $\left(22^{\circ} 27.33^{\prime}\right.$ N, $\left.114^{\circ} 21.00^{\prime} \mathrm{E}\right)$. Collected sponge colonies were flushed with autoclaved $0.22 \mu \mathrm{m}$ filtered seawater (AFSW) to remove loosely attached bacteria and sealed in sterile plastic bags for transportation to the laboratory. Approximately $550 \mathrm{ml}$ of sponge tissue were blot-dried, cut into small pieces and extracted twice in $550 \mathrm{ml}$ of 1:1 mixture of methanol/chloroform $\left(\mathrm{MeOH} / \mathrm{CHCl}_{3}\right)$ for $12 \mathrm{~h}$ each with gentle agitation. This 1:1 mixture of methanol/ chloroform solvent system could extract compounds of a wide range of polarity, including both polar and nonpolar metabolites from the sponge tissue. After extraction, sponge tissue was removed from the solvents by centrifugation. Then, the organic extract was separated into 2 layers $\left(\mathrm{MeOH}\right.$ and $\mathrm{CHCl}_{3}$ ) in a separation funnel and each layer was dried by rotary evaporation. In total, 10.1 and $14.3 \mathrm{~g}$ dry weight of $\mathrm{MeOH}$ and $\mathrm{CHCl}_{3}$ extracts were obtained, respectively.

Gel immobilization of tissue extracts and preparation of gel discs. The dry $\mathrm{MeOH}$ and $\mathrm{CHCl}_{3}$ extracts were re-dissolved in 1/20 of the original sponge tissue (i.e. $27.5 \mathrm{ml}$ ) of double-distilled water $\left(\mathrm{ddH}_{2} \mathrm{O}\right)$ and $\mathrm{CHCl}_{3}$, respectively. This resulted in 2 concentrated extracts, both at a concentration equivalent to $20 \times$ tissue level concentration (TLC). Extracts at 2 and $10 \times$ TLC were also prepared by dilution with corresponding solvents. Gel immobilization of the organic extracts was adopted from Henrikson \& Pawlik (1995) and Harder et al. (2004) with slight modifications. Briefly, $1 \mathrm{ml}$ of aliquots of each extract at 2,10 and $20 \times$ TLC were transferred to individual $15 \mathrm{ml}$ sterile polypropylene 
tubes (Falcon 2096), each of which contained $9 \mathrm{ml}$ of $4 \%$ (w/v) hydrogel (Phytagel $^{\mathrm{TM}}$, Sigma Chemical) solution prepared in hot $\mathrm{ddH}_{2} \mathrm{O}\left(\mathrm{ca} .70^{\circ} \mathrm{C}\right)$. The tubes were closed and turned upside down until hydrogel solutions therein were cooled to room temperature to yield transparent gel cylinders containing extracts at final concentrations of $0.2,1$ and $2 \times$ TLC. The gels were stored at $4^{\circ} \mathrm{C}$ overnight to allow the extract components to diffuse throughout the gel. Afterward, gel cylinders were sliced into $7 \mathrm{~mm}$ thick gel discs (volume of each disc is approx. $1 \mathrm{ml}$ ) using sterile razor blades. Among the 25 replicates prepared for each treatment, 5 were immediately subject to larval settlement bioassays for assessing the effect of the extract components on larval settlement; the remaining 20 were subject to microbial film development in flow-through seawater for either 24, 28, or $72 \mathrm{~h}$ (see below) (Fig. 1). Two sets of negative control gel discs were prepared accordingly using pure $\mathrm{ddH}_{2} \mathrm{O}$ and $\mathrm{CHCl}_{3}$, respectively. Positive control gel discs were prepared using concentrated antibiotic solutions, which yielded a final concentration of $219 \mathrm{mg} \mathrm{l}^{-1}$ penicillin $+365 \mathrm{mg} \mathrm{l}^{-1}$ streptomycin in the gel cylinder.

Development of microbial films on gel discs. Gel discs for each treatment were pierced with fishing line and anchored $10 \mathrm{~cm}$ below water surface in $10 \mathrm{l}$ aquaria continuously supplied with flowthrough, sand-filtered natural seawater delivered from a common source at a flow rate of $30 \mathrm{l}$ $\mathrm{h}^{-1}$. Discs from different treatments were separated in different aquaria to prevent potential cross-contamination by the leaching of extract components from the discs. The gel discs were retrieved after 24,48 or $72 \mathrm{~h}$. This time-series experiment was conducted for the purpose of developing microbial films with different bacterial densities, which were subsequently used for larval settlement bioassays (see below). The aim of this experiment was to gain a better understanding on the relationship between bacterial density in the microbial films and larval settlement of Hydroides elegans. Of the $20 \mathrm{gel}$ discs retrieved at each interval for each treatment, 3 were fixed with $4 \%$ formaldehyde for enumeration of bacterial cell density, 12 were subject to extraction of bacterial community DNA from the microbial films formed on the gel surface, and the remaining 5 were used for larval settlement bioassays (Fig. 1).

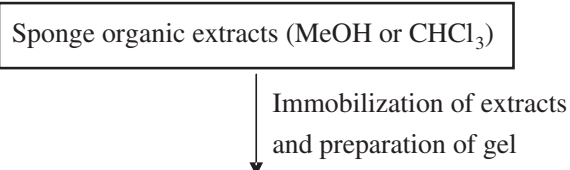

25 extract-containing gel discs

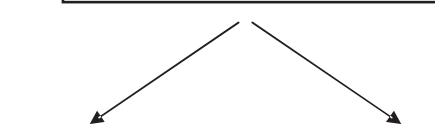
5 gel discs
20 gel discs

lement

t

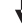

Objective

20 microbial

Development of microbial films for 24,48 or $72 \mathrm{~h}$

-coated gel discs

film-

$-1$
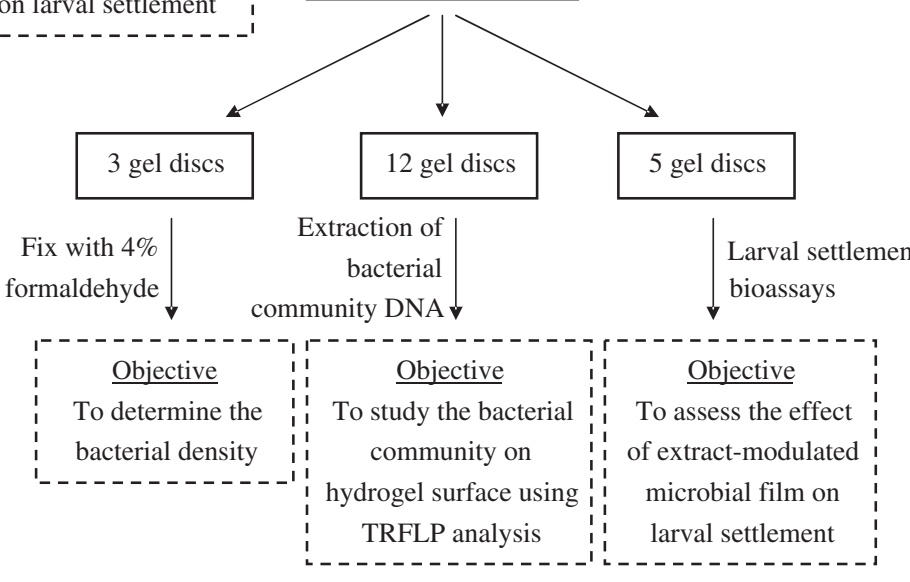

Fig. 1. Experimental setup for assessing the effects of sponge extracts on larval lement of Hydroides elegans and microbial film development on hydrogel surfaces. TRFLP: terminal restriction fragment length polymorphism

Determination of bacterial density. Formaldehydefixed gel discs $(n=3)$ were rinsed with $\mathrm{ddH}_{2} \mathrm{O}$, stained with the DNA-binding fluorochrome 4,6-diamidino-2phenylindole at a concentration of $0.5 \mu \mathrm{g} \mathrm{ml}^{-1}$ for $10 \mathrm{~min}$ at room temperature and then wet-mounted for epifluorescence microscopy. Bacterial cells were counted at $1000 \times$ magnification in 10 randomly chosen fields of view on each disc to determine bacterial density on gel surfaces.

Analysis of bacterial community composition using terminal restriction fragment length polymorphism (TRFLP). Gel discs for extraction of bacterial community DNA were rinsed with AFSW $(\mathrm{n}=4)$. Both sides of $3 \mathrm{gel}$ discs (ca. $9 \mathrm{~cm}^{2}$ in total) were thoroughly swabbed with a sterile cotton tip to collect the bacteria on disc surfaces. Each cotton tip was immediately frozen in $0.8 \mathrm{ml}$ of extraction buffer $(100 \mathrm{mM}$ Tris- $\mathrm{HCl}$, $100 \mathrm{mM} \mathrm{Na}$-EDTA, $100 \mathrm{mM} \mathrm{Na} \mathrm{HPO}_{4}, 1.5 \mathrm{M} \mathrm{NaCl}$, 
$1 \% \mathrm{CTAB}_{\text {; }}$ at $\mathrm{pH} 8$ ). Bacterial cell lysis, extraction of bacterial community DNA, PCR amplification of $16 \mathrm{~S}$ rRNA genes and enzymatic digestion of fluorescently labeled PCR products using Msp I followed the protocol described in Lee \& Qian (2003). PCR primers used were $341 \mathrm{~F}\left(5^{\prime}\right.$-CCTACGGGAGGCAGCAG-3') and 926R (5'-CCGTCAATTCCTTTRAGTTT-3') (Liu et al. 1997). The $5^{\prime}$ end of the $926 \mathrm{R}$ was tagged with the fluorescent dye FAM for detection of terminal restriction fragment by a MegaBace 500 genetic analyzer.

Larval settlement bioassays. Larvae of Hydroides elegans were obtained and raised according to Lau \& Qian (1997). Five gel discs retrieved from flow-through seawater (i.e. coated with microbial films) and 5 gel discs without prior exposure to seawater (i.e. without microbial films) were placed in individual wells in a 24 -well plate and covered with $1.5 \mathrm{ml}$ AFSW. To investigate the effect of microbial films on larval settlement, 15 competent larvae were added to each well that contained a film-coated gel discs. After $24 \mathrm{~h}$ incubation at $24^{\circ} \mathrm{C}$ on a $15: 9 \mathrm{~h}$ light dark photo-cycle, the percentage of larvae that had undergone settlement was determined by counting the number of individuals that had adhered to the gel surface and produce calcified tubes and tentacles. Additionally, percent survivorship in each treatment was scored as the sum of settled and free swimming larvae. Bioassays to investigate the potential larval settlement inhibition of organic extracts in gel discs followed the same procedures, except that gel discs without prior exposure to seawater (i.e. not coated with microbial films) were placed in individual wells and that each well received 15 larvae that had been exposed to $10^{-4} \mathrm{M}$ IBMX (3-isobutyl1-methylxanthine) $30 \mathrm{~min}$ prior to the bioassays. IBMX is a pharmacological compound that can effectively induce larval settlement of $H$. elegans (Qian \& Pechenik 1998).

Statistical analysis. Data in the form of bacterial density were log-transformed while data in the form of percentages of larval survivorship and settlement were arcsin-transformed before statistical analysis. Then, the normality of data was checked with Shapiro-Wilk's test (Shapiro \& Wilk 1965), and homogeneity of variance within samples was analyzed by Cochran's test. Data that met the assumptions of parametric tests were analyzed using either 1-way, 2-way or repeated measures ANOVA followed by Tukey's or Dunnett's test. Data that did not meet the assumptions of parametric analysis were analyzed by transforming values to ranks and then applying regular parametric tests (Conover \& Iman 1981). The correlation between mean $(n=3)$ bacterial density and mean $(n=5)$ percentage of larval settlement occurring on the gel surfaces was analyzed using Pearson product-moment correlation coefficient. For TRFLP analysis, terminal restriction fragments (TRFs) that were $<50$ fluorescence units in intensity, $<35 \mathrm{bp}$ in size, or $>500 \mathrm{bp}$ in size were excluded from statistical analysis in order to screen background noise, to avoid pseudo-TRFs derived from primers and to avoid inaccurate size determination, respectively (Möeseneder et al. 1999, Kitts 2001). TRFLP profiles were analyzed using multivariate techniques. The Sorenson coefficient was calculated based on the total number of TRFs in all samples and the presence or absence of these TRFs in individual samples to produce similarity matrices (Qian et al. 2003). Due to differential amplification of DNA during PCR (i.e. PCR bias, Suzuki \& Giovanni 1996), the signal intensity of TRFs may not reflect the actual abundance of the corresponding bacterial types and thus, was not considered in the analysis. Similarity matrices were used for non-parametric multi-dimensional scaling (MDS) ordinations using PRIMER program (Plymouth Routines In Multivariate Ecological Research, Clarke \& Warwick 1994). MDS ordinations with stress values $<0.2$ indicated that conclusions could be drawn with confidence (Clarke \& Warwick 1994).

\section{RESULTS}

\section{Bacterial densities on gel discs exposed for $72 \mathrm{~h}$}

After $72 \mathrm{~h}$ of exposure to flow-through seawater, bacterial densities on the surfaces of hydrogels prepared with $\mathrm{ddH}_{2} \mathrm{O}$ alone ( $\mathrm{ddH}_{2} \mathrm{O}$ control hereafter) and of hydrogels embedded with pure $\mathrm{CHCl}_{3}\left(\mathrm{CHCl}_{3}\right.$ control hereafter) were $\sim 160000$ cells $\mathrm{mm}^{-2}$ and there was no significant difference among them ( $p>0.993)$ whereas the hydrogels embedded with antibiotics (antibiotic control hereafter) had a significantly lower bacterial cell density of 30000 cells $\mathrm{mm}^{-2}$ ( $\left.\mathrm{p}<0.001\right)$. Bacterial densities on hydrogels embedded with different concentrations of $\mathrm{CHCl}_{3}$ extract $\left(\mathrm{CHCl}_{3}\right.$ extract-containing hydrogels hereafter) were similar to those on the $\mathrm{ddH}_{2} \mathrm{O}$ and $\mathrm{CHCl}_{3}$ control hydrogels $(\mathrm{p}>0.743)$. In contrast, bacterial densities on hydrogels embedded with $\mathrm{MeOH}$ extract $(\mathrm{MeOH}$ extract-containing hydrogels hereafter) ranged from 40000 to 70000 cells $\mathrm{mm}^{-2}$, which is similar to the antibiotic control hydrogels $(\mathrm{p}>$ 0.974).

\section{Composition of bacterial community on hydrogels exposed for $72 \mathrm{~h}$}

Despite the fact that bacterial communities derived from different treatments had different TRF profiles, 7 TRFs $(37,301,302,313,314,375$ and $423 \mathrm{bp})$ were commonly observed in all treatments (Table 1) and 6 
other TRFs $(179,311,312,315,370$ and $422 \mathrm{bp})$ were present in at least two-third of the treatments. Three TRFs (89, 90 and $206 \mathrm{bp}$ ), which were present in the $\mathrm{ddH}_{2} \mathrm{O}$ and $\mathrm{CHCl}_{3}$ control hydrogels, were not observed in any of the extract-containing hydrogels. In contrast, some TRFs (e.g. 80, 129, 207, 246, 365 and 371 bp), which were detected in at least 1 extract-contain-

Table 1. Terminal restriction fragments (TRFs) derived from bacterial communities on hydrogel surfaces of double-distilled water $\left(\mathrm{ddH}_{2} \mathrm{O}\right), \mathrm{CHCl}_{3}$, antibiotics, and different concentrations of $\mathrm{MeOH} / \mathrm{CHCl}_{3}$ extract $(0.2,1$ and $2 \times$ tissue level concentration [TLC]). Hydrogels had been exposed to natural flowthrough seawater for $72 \mathrm{~h}$. Data shown is the number of occurrences of a TRF in 4 replicates of a given sample while total absence of a TRF in a sample is indicated by a blank space

\begin{tabular}{|c|c|c|c|c|c|c|c|c|c|}
\hline \multirow{2}{*}{$\begin{array}{l}\text { TRF } \\
\text { (bp) }\end{array}$} & \multirow{2}{*}{$\mathrm{ddH}_{2} \mathrm{O}$} & \multicolumn{2}{|c|}{ Controls } & \multicolumn{3}{|c|}{$\mathrm{MeOH}$ extract } & \multicolumn{3}{|c|}{$\mathrm{CHCl}_{3}$ extract } \\
\hline & & $\mathrm{CHCl}_{3}$ & Antibiotics & $0.2 \times$ & $1 \times$ & $2 \times$ & $0.2 \times$ & $1 \times$ & $2 \times$ \\
\hline 37 & 4 & 3 & 4 & 2 & 3 & 2 & 3 & 4 & 2 \\
\hline 39 & & & 3 & 2 & & & & & 2 \\
\hline 40 & & & 4 & & & & & & 2 \\
\hline 53 & & & 2 & & & & & & \\
\hline 80 & & & & & & & & 4 & 4 \\
\hline 81 & & & & & & & & & 4 \\
\hline 89 & 4 & 2 & 2 & & & & & & \\
\hline 90 & 4 & 3 & & & & & & & \\
\hline 128 & & & & & 3 & & & & \\
\hline 129 & & & & & 4 & 4 & & & \\
\hline 130 & & & & 3 & & & & & \\
\hline 176 & & 2 & & & & & & & \\
\hline 179 & 4 & 4 & 3 & & 4 & & & 2 & 2 \\
\hline 180 & 4 & 3 & 2 & 2 & 2 & & & & \\
\hline 197 & & & & & & & 2 & & \\
\hline 206 & 4 & 3 & 3 & & & & & & \\
\hline 207 & & & & & & & & 4 & 4 \\
\hline 246 & & & & & 3 & 2 & & & \\
\hline 263 & 2 & 3 & & & 4 & & & & \\
\hline 299 & 3 & 4 & & & 3 & & & 4 & 4 \\
\hline 300 & & & & 2 & 2 & 2 & & & \\
\hline 301 & 4 & 4 & 4 & 4 & 4 & 4 & 4 & 4 & 4 \\
\hline 302 & 4 & 4 & 2 & 4 & 4 & 4 & 4 & 4 & 4 \\
\hline 309 & & & & & & & & 4 & \\
\hline 310 & 4 & & & & & & & 4 & \\
\hline 311 & 4 & 3 & 4 & 3 & & & 4 & 4 & 2 \\
\hline 312 & 3 & 4 & 4 & & 2 & & 3 & 2 & 2 \\
\hline 313 & 4 & 4 & 4 & 3 & 2 & 2 & 4 & 4 & 4 \\
\hline 314 & 4 & 4 & 4 & 4 & 4 & 4 & 4 & 4 & 3 \\
\hline 315 & & 4 & 2 & & 2 & & 4 & 4 & 3 \\
\hline 365 & & & & & 4 & 3 & & & 2 \\
\hline 366 & & 3 & & & & & & & \\
\hline 368 & 2 & & & 3 & 4 & 4 & & & 2 \\
\hline 369 & & & & 3 & & & & & \\
\hline 370 & 3 & 4 & 3 & 2 & 3 & 2 & & 3 & 3 \\
\hline 371 & & & 2 & 3 & 2 & 2 & 2 & & \\
\hline 372 & & & & 2 & 2 & & & & \\
\hline 375 & 4 & 4 & 4 & 4 & 3 & 2 & 4 & 4 & 4 \\
\hline 376 & 4 & & & 4 & & 2 & & & \\
\hline 419 & 3 & & & & 2 & & & & \\
\hline 420 & 3 & 4 & & & 4 & & 2 & & 2 \\
\hline 421 & & & & & 4 & & & & \\
\hline 422 & 3 & 3 & 3 & & 4 & 2 & 4 & 4 & 4 \\
\hline 423 & 4 & 4 & 4 & 4 & 3 & 2 & 3 & 4 & 4 \\
\hline 424 & & & 2 & & & & & & \\
\hline
\end{tabular}

ing hydrogels, were not detected in the $\mathrm{ddH}_{2} \mathrm{O}$ and $\mathrm{CHCl}_{3}$ control hydrogels.

MDS ordinations arranged the bacterial communities, derived from the $3 \mathrm{MeOH}$ extract-containing hydrogels $(0.2,1$ and $2 \times$ TLC), into 4 distinctive groups, which were clearly separated from 2 other groups for the $\mathrm{ddH}_{2} \mathrm{O}$ and antibiotic control hydrogels

(Fig. 2a). Each group contained hydrogels with similarity $>70 \%$. Similarly, bacterial communities derived from the $3 \mathrm{CHCl}_{3}$ extract-containing hydrogels were formed into 2 groups that were clearly distinguishable from all the control hydrogels (Fig. 2b).

\section{Larval settlement on hydrogels without microbial films}

After $24 \mathrm{~h}$ of bioassay, 68 and $61 \%$ of larvae settled on the $\mathrm{ddH}_{2} \mathrm{O}$ and $\mathrm{CHCl}_{3}$ control hydrogels, respectively, that had not been exposed to flowthrough seawater (i.e. without microbial films). Percent larval settlement on the $\mathrm{MeOH}$ or $\mathrm{CHCl}_{3}$ extract-containing hydrogels were similar to that on the hydrogels of the 2 controls ( $p>$ 0.832 ). No mortality of larvae was recorded during the assay period.

\section{Larval settlement on hydrogels coated with microbial films}

Prior to the bioassay, hydrogels were exposed to flow-through seawater for $72 \mathrm{~h}$ for the formation of microbial films. After $24 \mathrm{~h}$ of bioassay, $>90 \%$ of survivorship was recorded for larvae that were exposed to the $\mathrm{H}_{2} \mathrm{O}$ control hydrogels, the antibiotic control and the $\mathrm{MeOH}$ extract-containing hydrogels (Fig. 3a). Survivorship for larvae exposed to the $\mathrm{CHCl}_{3}$ control hydrogels was reduced to $62 \%$. Survivorship was further reduced to 1 to $32 \%$ for larvae that had been exposed to the $\mathrm{CHCl}_{3}$ extract-containing hydrogels (Fig. 3a).

Larval settlement on the hydrogels of the $\mathrm{ddH}_{2} \mathrm{O}, \mathrm{CHCl}_{3}$ and antibiotic controls were 85,63 and $69 \%$ (of the total number of larvae added to each well), respectively ( $p>0.04$; Fig. 3b). 

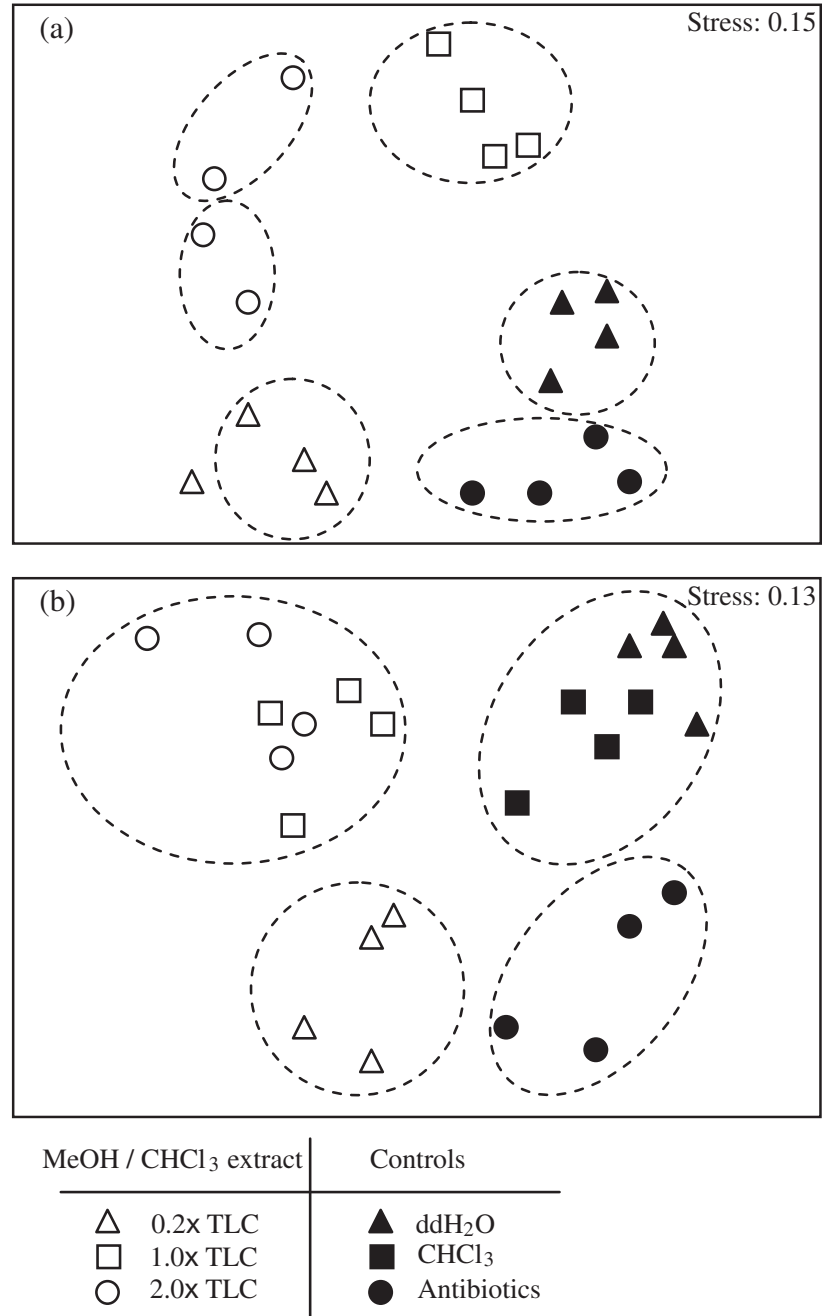

Fig. 2. Multi-dimensional scaling (MDS) ordinations of bacterial communities (4 replicates each) on surfaces of hydrogels with $0.2,1$ and $2 \times$ tissue level concentration (TLC) of (a) $\mathrm{MeOH}$ and (b) $\mathrm{CHCl}_{3}$ extracts compared with the doubledistilled water $\left(\mathrm{ddH}_{2} \mathrm{O}\right), \mathrm{CHCl}_{3}$ and antibiotic controls. Hydrogels had been exposed to natural flow-through seawater for $72 \mathrm{~h}$. Samples within circles in dotted-line indicate samples with similarity $>70 \%$

Percent larval settlement on the $\mathrm{MeOH}$ extract-containing hydrogels, except those with $0.2 \times \mathrm{TLC} \mathrm{MeOH}$ extract, did not differ from that on the $\mathrm{ddH}_{2} \mathrm{O}$ control hydrogels ( $p$ > 0.497). Larval settlement on the $\mathrm{CHCl}_{3}$ extract-containing hydrogels were reduced to 0 to $20 \%$ of total number of larvae added.

\section{Bacterial community formation and larval settlement on hydrogel exposed to flow-through seawater for different durations}

In general, bacterial densities on hydrogel surface increased with the duration of exposure to flow-though seawater (Fig. 4). Bacterial densities on hydrogel surfaces of the $\mathrm{ddH}_{2} \mathrm{O}$ control developed for different durations were the highest among all treatments at all times (Fig. 4). After $24 \mathrm{~h}$ of exposure to seawater, bacterial densities on the 1 and $2 \times$ TLC MeOH extractcontaining hydrogels were significantly lower than that on the $\mathrm{ddH}_{2} \mathrm{O}$ control hydrogels $(\mathrm{p}<0.05)$. However, after $48 \mathrm{~h}$ of exposure, only the $2 \times \mathrm{TLC} \mathrm{MeOH}$ extract-containing hydrogels showed significantly lower bacterial density than that on the control hydrogels $(p<0.05)$. In contrast, after $72 \mathrm{~h}$ of exposure, bacterial densities on all the $\mathrm{MeOH}$ extract-containing hydrogels were significantly lower than that on the control hydrogels $(p<0.05)$. Repeated measures ANOVA revealed that both the extract concentration in hydrogel and the exposure time of hydrogel to flowthrough seawater had significant effects on bacterial cell density, with significant interaction among these 2 factors ( $\mathrm{p}<0.001$; Fig. 4).
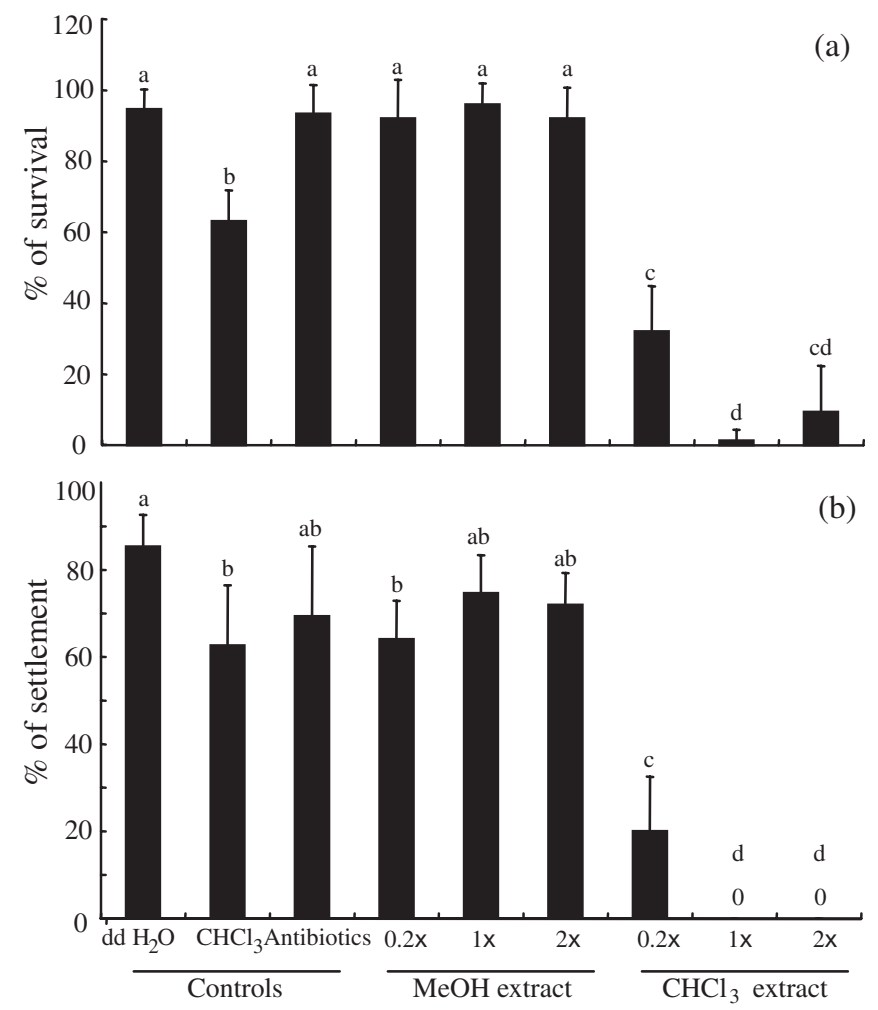

Fig. 3. Hydroides elegans. Percent (a) survivorship and (b) settlement of larvae after $24 \mathrm{~h}$ exposure to hydrogels that had been submerged in flow-through seawater for $72 \mathrm{~h}$. $\mathrm{ddH}_{2} \mathrm{O}, \mathrm{CHCl}_{3}$ and antibiotics represent the 3 controls whereas $0.2 \times, 1 \times$ and $2 \times$ indicate $\mathrm{MeOH}$ and $\mathrm{CHCl}_{3}$ extracts at $0.2,1$ and $2 \times$ TLC, respectively. Data shown are mean $+\mathrm{SD}$ for 5 replicates. Data for larval settlement are expressed as mean percent of total number of larvae added to each treatment. Data that are significantly different at $\alpha=0.05$ in Tukey's test are indicated by different letters above the bars 


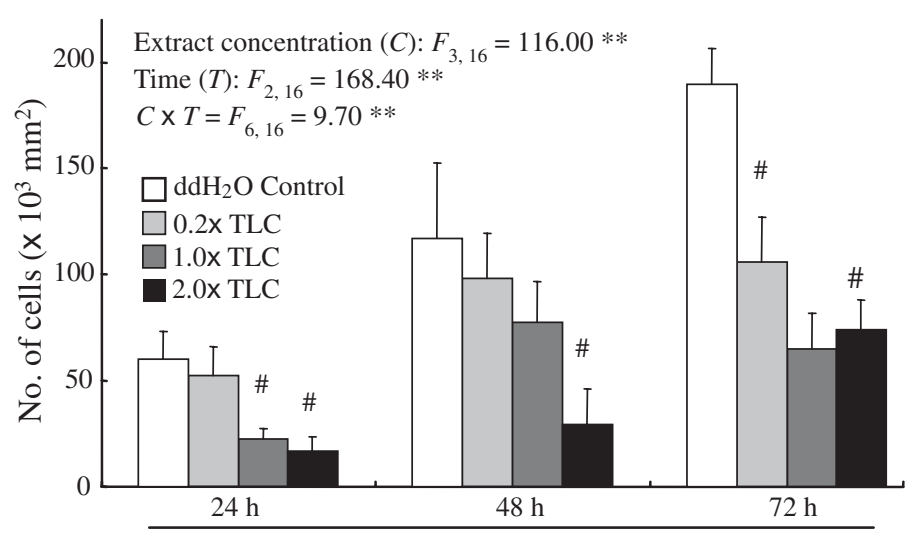

Exposure time to natural seawater

Fig. 4. Bacterial density on surfaces of hydrogels with different concentrations of $\mathrm{MeOH}$ extract $(0.2,1$ and $2 \times$ TLC) exposed to natural seawater for different durations. Open bars represent the $\mathrm{ddH}_{2} \mathrm{O}$ controls. Data shown are mean $+\mathrm{SD}$ for 3 replicates with pseudo-replication $(\mathrm{n}=10)$ in each replicate. Data that are significantly different from the corresponding control at $\alpha=0.05$ in Dunnet's test are indicated by \# above the bars. Data on the upper left corner show the effect of concentration of the $\mathrm{MeOH}$ extract in hydrogel $(C)$, exposure time of hydrogel to flow-through seawater $(T)$ and their interaction on bacterial cell density analyzed by repeated measures ANOVA. Data were log-transformed before statistical analysis. ${ }^{* *}$ p-value less than 0.001

MDS ordinations of TRF profiles revealed that bacterial communities on the surfaces of the $\mathrm{ddH}_{2} \mathrm{O}$ control hydrogels were distinguishable from those on the $\mathrm{MeOH}$ extract-containing hydrogels at all times (stress values <0.2; Fig. 5). Bacterial communities on the $\mathrm{MeOH}$ extract-containing hydrogels with different extract concentrations were distinguishable only after $72 \mathrm{~h}$ of exposure to seawater (Fig. 5).

The microbial film-coated hydrogels were then exposed to larvae of Hydroides elegans. Results indicated that larval settlement on the $\mathrm{MeOH}$ extract-containing hydrogels exposed for different durations ranged from 60 to $92 \%$ (Fig. 6). When comparing larval settlement response towards microbial films on the $\mathrm{MeOH}$ extractcontaining hydrogels with that on the $\mathrm{ddH}_{2} \mathrm{O}$ control hydrogels, the 1 and $2 \times$ TLC extract-containing hydrogels exposed for $24 \mathrm{~h}$, the $2 \times$ TLC extract-containing hydrogels exposed for $48 \mathrm{~h}$, and the 0.2 and $1 \times$ TLC extract-containing hydrogels exposed for $72 \mathrm{~h}$ showed significant reductions in percentage of larval settlement ( $p<0.05$; Fig. 6). Two-way ANOVA revealed significant effects of extract concentration in hydrogel and exposure time of hydrogel to flow-through seawater on larval settlement of $H$. elegans, as well as a significant interaction between these 2 factors ( $p<0.05$; Fig. 6). There was a significant positive correlation between bacterial density on the hydrogel surfaces and percentage of larval settlement ( $r=0.65$; Fig. 7 ).

\section{DISCUSSION}

This study investigated hypothetical roles of sponge metabolites in defending the sponge Mycale adhaerens against epibiosis through the modulation of bacterial community on the sponge surface. We used a bacterial-culture-independent technique that allowed a more ecologically realistic investigation than conventional, bacterial-culture-dependent methods. Using this technique, hydrogels containing organic extracts of sponge tissue were exposed to a natural bacterial community in flow-through seawater so as to mimic bacterial colonization of sponge surface in the natural environment (Harder et al. 2004; Fig. 1 present study). Microbial films formed on the hydrogel surface were subsequently analyzed for bacterial community
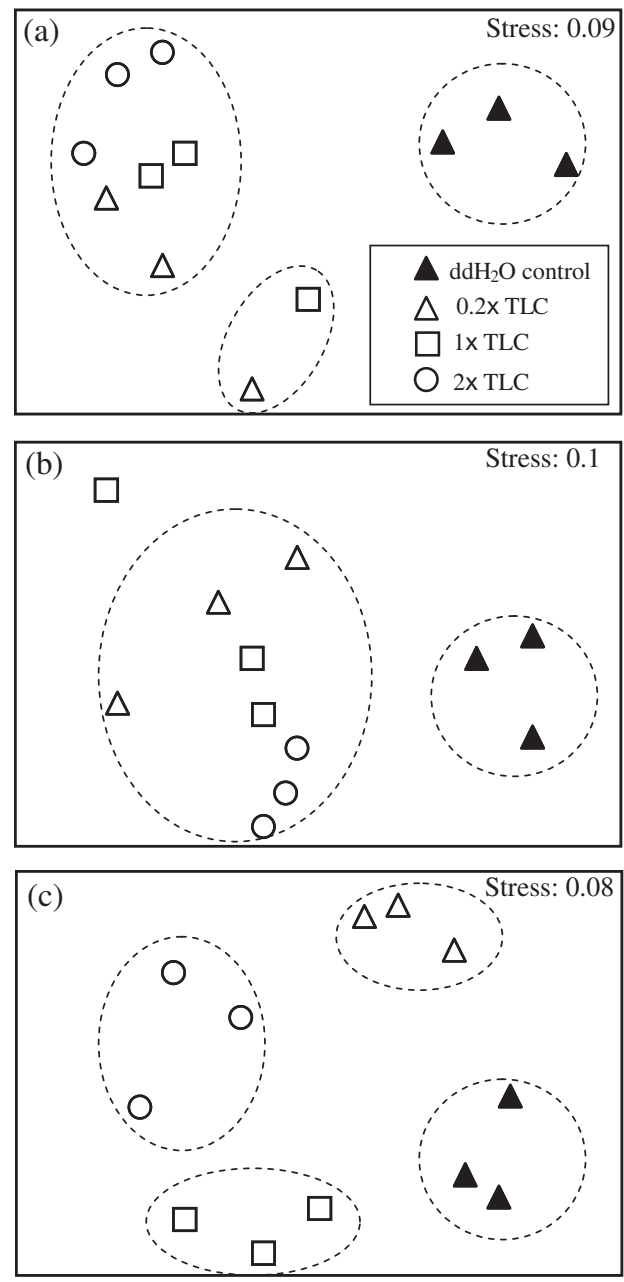

Fig. 5. MDS ordinations of bacterial communities (3 replicates each) on surfaces of hydrogels with $0.2,1$ and $2 \times$ TLC of $\mathrm{MeOH}$ extract compared with the $\mathrm{ddH}_{2} \mathrm{O}$ controls. Microbial films were developed for (a) 24, (b) 48 and (c) $72 \mathrm{~h}$. Groups in dotted-lines differed by more than $50 \%$ 


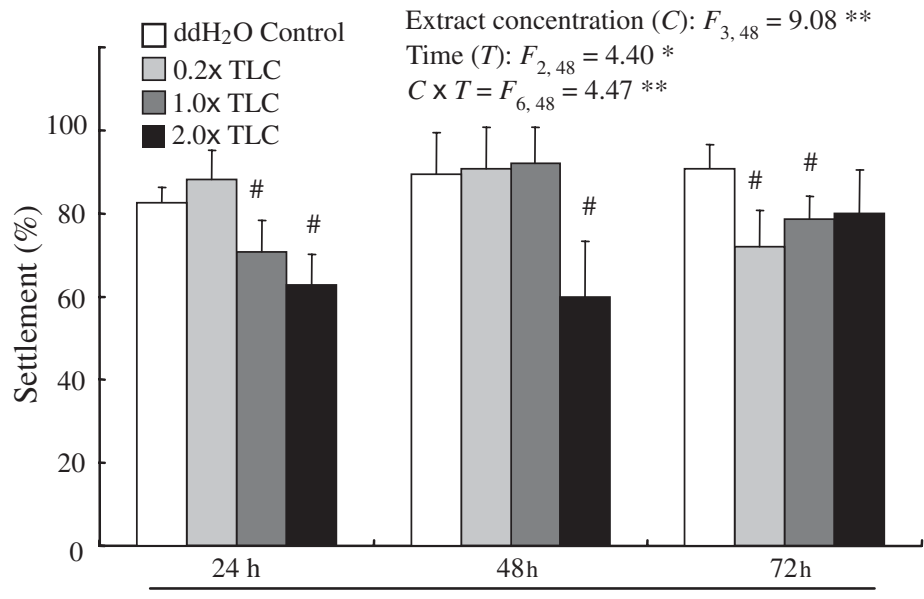

Exposure time to natural seawater

Fig. 6. Hydroides elegans. Percent settlement of larvae on surfaces of hydrogels with different concentrations of $\mathrm{MeOH}$ extract $(0.2,1$ and $2 \times$ TLC) exposed to natural seawater for different durations. Open bars represent $d_{d d H_{2}} \mathrm{O}$ controls. Data expressed as mean percent of total number of larvae added to each treatment. Data shown are mean + SD for 5 replicates. Data that are significantly different from the corresponding control at $\alpha=0.05$ in Dunnet's test are indicated by \# above the bars. Data on the upper right corner show the effect of concentration of the $\mathrm{MeOH}$ extract in hydrogel $(C)$, exposure time of hydrogel to flow-through seawater $(T)$ and their interaction on larval settlement of $H$. elegans analyzed by 2-way ANOVA. Data were arcine-transformed before statistical analysis. ${ }^{* *}$ p-values less than $0.001,{ }^{*}$ p-values less than 0.05

composition and tested for effects on larval settlement (Fig. 1).

Results indicated that both $\mathrm{MeOH}$ and $\mathrm{CHCl}_{3}$ extracts could affect bacterial colonization. The $\mathrm{MeOH}$ extract, which presumably contained relatively polar sponge metabolites, affected bacterial colonization by both reducing bacterial cell density (Fig. 4) and altering bacterial community diversity (Figs. 2a \& 5). On the other hand, the $\mathrm{CHCl}_{3}$ extract, which presumably contained less polar sponge metabolites, altered bacterial community diversity (Fig. 2b) without reducing bacterial cell density. TRFs of 89, 90 and 206 bp present on the $\mathrm{ddH}_{2} \mathrm{O}$ or $\mathrm{CHCl}_{3}$ control hydrogels were absent from the bacterial communities developed on the extract-containing hydrogels (Table 1), suggesting an inhibitive effect of sponge extract components on colonization of certain bacterial types on hydrogel surfaces. The inhibitive effect may include inhibition of growth, attachment, and/or chemotaxis. These results are congruent to our early findings in disc diffusion assays that the $\mathrm{CHCl}_{3}$ extract of Mycale adhaerens significantly inhibited bacterial growth (Lee \& Qian 2004). In fact, antibacterial and anti-attachment activities of compounds from various sponges have also been reported in many other studies (Newbold et al. 1999, Kelly et al. 2003, Ely et al. 2004). These inhibitive activities may form a line of chemical defense against colonization by pathogenic or harmful bacteria in sponges.

In this study, the whole sponge tissues were used for organic extraction instead of just extracting the surface layer where epibiosis occurs. One may argue that different parts of sponge tissues produce different metabolites and the metabolites extracted from the whole sponge tissues may not necessarily present at the sponge surface. However, one may also argue that high porosity and effective water circulatory system in the sponge allows a good share of metabolites throughout the whole sponge tissue; polar metabolites from inner tissue will easily diffuse out and reach the surface level, while non-polar ones may also be transported to the surface level by free-moving amoebocytes. A good example of this can be found in Kubanek et al. (2002), who demonstrated that triterpene glycosides, which exhibited potent antifouling activity, were found in all different layers of the sponge Erylus formosus. Interestingly, the compounds were at the lowest concentration in the surface layer but the most abundant in the third inner layer of the sponge. This may suggest that the site of production of bioactive compounds may not necessarily be the same as the site of action.

Despite the observed inhibitive effects of the $\mathrm{MeOH}$ and $\mathrm{CHCl}_{3}$ extracts on bacterial colonization, some bacteria (such as those represented by TRFs at 80, 129 and $371 \mathrm{bp}$ on the extract-containing hydrogels)
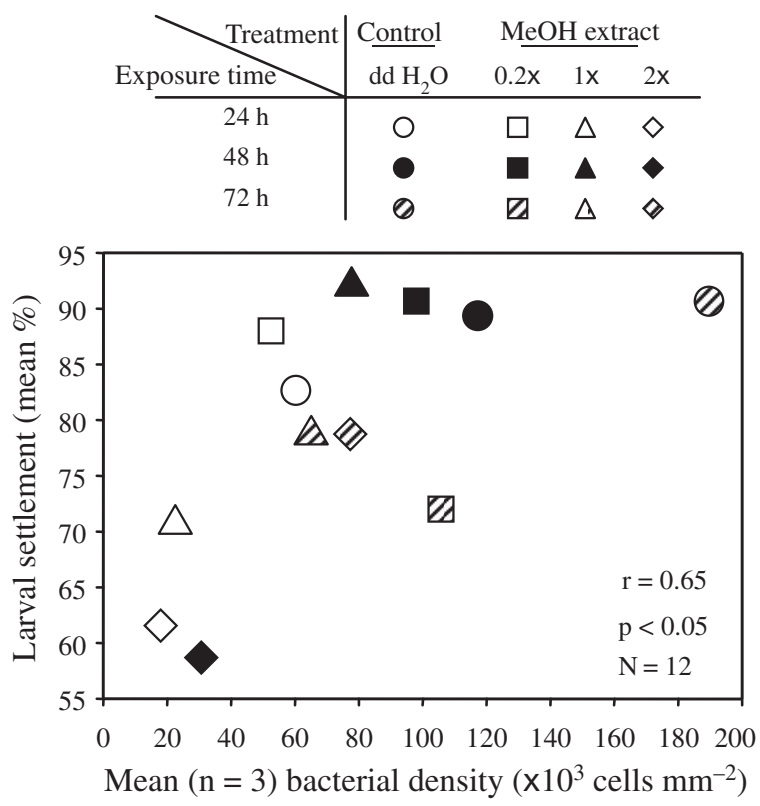

Fig. 7. Hydroides elegans. Correlation between mean percent larval settlement $(n=5)$ to mean bacterial density $(n=3)$ 
appeared to be enriched by these extracts (Table 1). It has been suggested that sponges have evolved secondary metabolites with specific enrichment effects to nurture distinctive groups of bacterial associates (Hentschel et al. 2001, Harder et al. 2004) that may have multiple beneficial roles to the sponge hosts, including defense against pathogenesis and epibiosis, and mobilization of nutrient sources that are otherwise not utilizable by sponges (Wahl 1989).

The bacterial communities on the extract-containing hydrogels developed for $72 \mathrm{~h}$ in this study significantly differed from those on the sponge surface determined in our previous study (Lee \& Qian 2003) (data not shown). It is not surprising that a bacterial community that has been developed for months or years on a live sponge in the natural environment differs from the one that has been developed only for $72 \mathrm{~h}$ on an artificial surface under laboratory condition. However, in both cases, the observed inhibition or promotion of colonization of certain kinds of bacteria may indicate antiepibiosis or recruitment of potentially beneficial bacteria on the sponge surface.

On the other hand, the microbial films developed on the $\mathrm{CHCl}_{3}$ extract-containing hydrogels had a toxic effect on the larvae of Hydroides elegans, indicated by massive larval mortality within $24 \mathrm{~h}$ of exposure to the $\mathrm{CHCl}_{3}$ extract-containing hydrogels coated with $3 \mathrm{~d}$ old microbial films (Fig. 3a). The toxicity was unlikely due to the extract components or residual $\mathrm{CHCl}_{3}$ since the same hydrogels (i.e. $\mathrm{CHCl}_{3}$ extract-containing and $\mathrm{CHCl}_{3}$ control) without microbial film (i.e. without prior exposure to seawater) did not cause any mortality. The massive mortality caused by the microbial film-coated, $\mathrm{CHCl}_{3}$-extract containing hydrogels suggested that the toxicity might be due to microbial utilization of extract components, which resulted in either toxic metabolites or the enrichment of a harmful microbial communities to larvae on the hydrogel surface. Microbial utilization of $\mathrm{CHCl}_{3}$ might have also contributed to the toxicity since a low-level mortality was also observed in the $\mathrm{CHCl}_{3}$ control coated with a microbial film.

Further, variations in larval settlement response of Hydroides elegans to microbial films developed for different durations on the $\mathrm{MeOH}$ extract-containing hydrogels (Fig. 6) were unlikely due to the extract components since larval settlement on the same hydrogels (i.e. $\mathrm{MeOH}$ extract-containing) without microbial film (i.e. without prior exposure to seawater) was the same as that on the $\mathrm{ddH}_{2} \mathrm{O}$ control hydrogels (data not shown). These variations in larval settlement response may be due to the decrease in bacterial density caused by the $\mathrm{MeOH}$ extract. This argument was at least partially supported by the fact that (1) there were significant reductions in bacterial densities on the $\mathrm{MeOH}$ extract-containing hydrogels (Fig. 4), and (2) there was a positive correlation between bacterial density and larval settlement of $H$. elegans (Fig. 7); a similar case is reported in Qian (1999) and in Huang \& Hadfield (2003). On the other hand, the substantial alternation of the bacterial community diversity on the hydrogel surfaces by the $\mathrm{MeOH}$ extract (Fig. 5) may also lead to the variations in larval settlement because bacterial species composition in a microbial film can determine the film's bioactivity (inductive, inhibitive or have no effect) on $H$. elegans larval settlement (Qian 1999, Lau et al. 2002). Indeed, many soft-bodied invertebrates may inhibit epibiosis (i.e. growth and settlement of other organisms on their body surfaces) through suppressing colonization of inductive bacterial strains or enhancing colonization of non-inductive ones (Holmström et al. 1992, James et al. 1996, Dobretsov \& Qian 2004). The same can be true in Mycale adhaerens because the culturable population of the bacterial community on the sponge surface was dominated by bacteria with inhibitive or non inductive effects on H. elegans larval settlement (Lee \& Qian 2003).

By coupling bacterial-culture-independent technique and larval settlement bioassays, this study, for the first time, allowed an in situ assessment of anticolonization activities of extract components of the sponge Mycale adhaerens against a natural bacterial community under flow conditions, with no restriction to particular modes of bacterial colonization (e.g. antigrowth or repellant) and indirect effects on larval settlement of fouling organisms. Our results demonstrated that the organic extracts of the sponge were able to modulate the bacterial community of a microbial film by reducing bacterial abundance and/or altering bacterial diversity, suggesting a chemically modulation of bacterial community on the sponge surface by sponge metabolites. This modulation might change the bioactivity of the microbial film for larval settlement by imposing either a toxic or an anti-settlement effect on larvae, which may aid the sponge to defend against colonization by epibiotic organisms; a possible indirect control of epibiosis in the sponge was suggested. Future studies on identifying the metabolites responsible for this potential defense would help to elucidate the indirect anti-epibiosis mechanism in this sponge.

Acknowledgements. The authors thank V. Thiyagarajan for consultation of statistical analysis and Y. K. Tam for assistance in TRFLP analysis. The study was supported by a RGC grant (HKUST6240/04M) to P.-Y.Q.

\section{LITERATURE CITED}

Acar JF (1980) The disc susceptibility test. In: Lorian V (ed) Antibiotics in laboratory and medicine. Williams \& Wilkins, Baltimore, MD, p 24-54 
Aceret TL, Coll JC, Uchio Y, Sammarco PW (1998) Antimicrobial activity of the diterpenes flexibilide and sinulariolide derived from Sinularia flexibilis Quoy and Gaimard 1833 (Coelenterata: Alcyonacea, Octocorallia). Comp Biochem Physiol Part C Pharmacol Toxicol Endocrinol 120(1) 121-126

Amade P, Charroin C, Baby C, Bacelet J (1987) Antimicrobial activities of marine sponges from the Mediterranean Sea. Mar Biol 94:271-275

Clarke KR, Warwick RM (1994) Changes in marine communities: an approach to statistical analysis and interpretation. Bourne Press, Bournemouth

Conover WJ, Iman L (1981) Rank transformations as a bridge between parametric and nonparametric statistics. Am Stat 35:124-129

Davis AR, Wright AE (1990) Inhibition of larval settlement by natural products from the ascidian, Endistoma olivaceum (Van Name). J Chem Ecol 16:1349-1357

Davis AR, Targett NM, McConnell OJ, Young CM (1989) Epibiosis of marine algae and benthic invertebrates: natural products chemistry and other mechanisms inhibiting settlement and overgrowth. In: Suheuer PJ (ed) Bioorganic marine chemistry. Springer-Verlag, Berlin, p 85-114

Dixon J, Schroeter SC, Kastendiek J (1981) Effects of encrusting bryozoan, Membranipora membranacea, on the loss of blades and fronds by the giant kelp, Macrocystis pyrifera (Laminariales). J Phycol 17:341-345

Dobretsov S, Qian PY (2004) The role of epibiotic bacteria from the surface of the soft coral Dendronephthya sp. in the inhibition of larval settlement. J Exp Mar Biol Ecol 299(1):35-50

Dobretsov S, Dahms HU, Tsoi MY, Qian PY (2005) Chemical control of epibiosis by Hong Kong sponges: the effect of sponge extracts on micro- and macrofouling communities. Mar Ecol Prog Ser 297:119-129

Ely R, Supriya T, Naik CG (2004) Antimicrobial activity of marine organisms collected off the coast of South East India. J Exp Mar Biol Ecol 309:121-127

Gerhart DJ, Rittschof D, Mayo SW (1988) Chemical ecology and the search for marine antifoulants. Studies of a predator-prey symbiosis. J Chem Ecol 14(10):1905-1918

Harder T, Lam C, Qian PY (2002) Larval settlement induction of the polychaete Hydroides elegans (Haswell) by marine biofilms: an investigation of monospecific fouling diatoms as settlement cues. Mar Ecol Prog Ser 229:105-112

Harder T, Lau SCK, Tam WY, Qian PY (2004) A bacterial culture-independent method to investigate chemically mediated control of bacterial epibiosis in marine invertebrates by using TRFLP analysis and natural bacterial populations. FEMS Microbiol Ecol 47:93-99

Henrikson AA, Pawlik JR (1995) A new antifouling assay method: results from field experiments using extracts of four marine organisms. J Exp Mar Biol Ecol 194:157-165

Hentschel U, Schmid M, Wagner M, Fieseler L, Gernert C, Hacker J (2001) Isolation and phylogenetic analysis of bacteria with antimicrobial activities from the Mediterranean sponges Aplysina aerophoba and Aplysina cavernicola. FEMS Microbiol Ecol 35(3):305-312

Hirota H, Tomono Y, Fusetani N (1996) Terpenoids with antifouling activity against barnacle larvae from the marine sponge Acanthella cavernosa. Tetrahedron 52: 2359-2368

Holmström C, Rittschof D, Kjelleberg S (1992) Inhibition of settlement by larvae of Balanus amphitrite and Cliona intestinalis by surface-colonizing marine bacterium. Appl Environ Microbiol 58:2111-2115

Huang S, Hadfield MG (2003) Composition and density of bacterial biofilms determine larval settlement of the polychaete Hydroides elegans. Mar Ecol Prog Ser 260:161-172

James G, Holmström C, Kjelleberg S (1996) Purification and characterization of a novel antibacterial protein from the marine bacterium D2. Appl Environ Microbiol 62: 2783-2788

Keifer PA, Schwartz RE, Koker MES, Hughes RG, Rittschof D, Rinehart KL (1991) Bioactive bromopyrrole metabolites from the Caribbean sponge Agelas conifera. J Org Chem 56:2965-2975

Kelly SR, Jensen PR, Henkel T, Fenical W, Pawlik JR (2003) Effect of Caribbean sponge extracts on bacterial attachment. Aquat Microb Ecol 31:175-182

Keough MJ (1984) Dynamics of the epifauna of the bivalve Pinna bicolor: interactions among recruitment, predation, and competition. Ecology 65(3):677-688

Kitts CL (2001) Terminal restriction fragment patterns: a tool for comparing microbial communities and assessing community dynamics. Curr Issues Intest Microbiol 2(1):17-25

Kubanek J, Whalen KE, Engel S, Kelly SR, Henkel TP, Fenical W, Pawlik JR (2002) Multiple defensive roles for triterpene glycosides from two Caribbean sponges. Oceologia 131: 125-136

Lau SCK, Qian PY (1997) Phlorotannins and related compounds as larval settlement inhibitors of the tube-building polychaete Hydroides elegans. Mar Ecol Prog Ser 159: $219-227$

Lau SCK, Mak KKW, Chen F, Qian PY (2002) Bioactivity of bacterial strains from marine biofilms in Hong Kong waters for the induction of larval settlement in the marine polychaete Hydroides elegans. Mar Ecol Prog Ser 226: 301-310

Lee OO, Qian PY (2003) Chemical control of bacterial epibiosis and larval settlement of Hydroides elegans in the red sponge Mycale adhaerens. Biofouling 19:171-180

Lee OO, Qian PY (2004) Potential control of bacterial epibiosis on the surface of the sponge Mycale adhaerens. Aquat Microb Ecol 34:11-21

Lesser MP, Shumway SE, Cucci T, Smith J (1992) Impact of fouling organisms on mussel rope culture: interspecific competition for food among suspension-feeding invertebrates. J Exp Mar Biol Ecol 165:91-102

Liu WT, Marsh TL, Cheng K, Forney LJ (1997) Characterization of microbial diversity by determining terminal restriction fragment length polymorphisms of genes encoding 16S rRNA. Appl Environ Microbiol 63:4516-4522

Maki JS (1999) The influence of marine microbes on biofouling. In: Fingerman M, Nagabhushanam R, Thompson M (eds) Recent advances in marine biotechnology. Science Publishers, Enfield, NH, p 147-171

Möeseneder MM, Arrieta JM, Muyzer G, Winter C, Herndl GJ (1999) Optimization of terminal-restriction fragment length polymorphism analysis for complex marine bacterioplankton communities and comparison with denaturing gradient gel electrophoresis. Appl Environ Microbiol 65: 3518-3525

Newbold RW, Jensen PR, Fenical W, Pawlik JR (1999) Antimicrobial activity of Caribbean sponge extracts. Aquat Microb Ecol 19:279-284

Okino T, Yoshimura E, Hirota H, Fusetani N (1996) New antifouling kalihipyrans from the marine sponge Acanthella cavernosa. J Nat Prod 59(11):1081-1083

Pace NR (1996) New prospective on the natural microbial world: molecular microbial ecology. ASM News 62: 463-270

Qian PY (1999) Larval settlement of polychaetes. Hydrobiologia 402:239-253 
Qian PY, Pechenik JA (1998) Effects of larval starvation and delayed metamorphosis on juvenile survival and growth of the tube-dwelling polychaete Hydroides elegans (Haswell). J Exp Mar Biol Ecol 227(2):169-185

Qian PY, Thiyagarajan V, Lau SCK, Cheung SCK (2003) Relationship between bacterial community profile in biofilm and attachment of the acorn barnacle Balanus amphitrite. Aquat Microb Ecol 33:225-237

Shapiro SS, Wilk MB (1965) An analysis of variance test for normality (complete samples). Biometrika 52:591-611

Standing J, Hooper IR, Costlow JD (1984) Inhibition and induction of barnacle settlement by natural products present in octocorals. J Chem Ecol 10:823-834

Suzuki MT, Giovanni SJ (1996) Bias caused by template

Editorial responsibility: Staffan Kjelleberg,

Sydney, Australia annealing in the amplification of mixtures of 16S rRNA genes by PCR. Appl Environ Microbiol 62:625-630

Wahl M (1989) Marine epibiosis. I. Fouling and antifouling: some basic aspects. Mar Ecol Prog Ser 58:175-189

Wahl M, Mark O (1999) The predominantly facultative nature of epibiosis: experimental and observational evidence. Mar Ecol Prog Ser 187:59-66

Wieczorek SK, Todd CD (1997) Inhibition and facilitation of bryozoan and ascidian settlement by natural multi-species biofilms: effects of film age and the roles of active and passive larval attachment. Mar Biol 128(3):463-473

Witman JD, Suchanek TH (1984). Mussels in flow: drag and dislodgement by epizoans. Mar Ecol Prog Ser 110: $45-47$

Submitted: July 1, 2005; Accepted: February 4, 2006 Proofs received from author(s): April 13, 2006 